\title{
Predation of the Buffy-fronted Seedeater Sporophila frontalis (Aves: Emberizidae) on Merostachys neesii (Poaceae: Babusoideae) seeds during a masting event in the Atlantic forest
}

\author{
César Cestari ${ }^{1,3}$ \& Cláudio João Bernardi ${ }^{2}$ \\ ${ }^{1}$ Programa de Pós-graduação em Zoologia, Departamento de Zoologia, \\ Universidade Estadual Paulista “Júlio de Mesquita Filho" - UNESP, Campus de Rio Claro, \\ CEP 13506-900, Rio Claro, São Paulo, Brazil \\ ${ }^{2}$ Programa de Pós-graduação em Biologia Vegetal, \\ Universidade Estadual Paulista "Júlio de Mesquita Filho" - UNESP, Campus de Rio Claro, \\ CEP 13506-900, Rio Claro, São Paulo, Brazil \\ ${ }^{3}$ Corresponding author: César Cestari, e-mail: cesar_cestari@yahoo.com.br
}

CESTARI, C. \& BERNARDI, C.J. Predation of the Buffy-fronted Seedeater Sporophila frontalis (Aves: Emberezidae) on Merostachys neesii (Poaceae: Babusoideae) seeds during a masting event in the Atlantic forest. Biota Neotrop. 11(3): http://www.biotaneotropica.org.br/v11n3/en/abstract?shortcommunication+bn00711032011

\begin{abstract}
The Buffy-fronted Seedeater Sporophila frontalis (Verreaux, 1869) is frequently found foraging on seeds during ephemeral masting events of bamboos in the Atlantic forest. In the present study, we analyzed the predation activity of $S$. frontalis on seeds of Merostachys neesii Rupr. during a masting event in an Atlantic forest reserve on southeastern Brazil. We conducted point counts in spots with M. neesii and in spots without bamboos along trails to determine the presence of $S$. frontalis on $M$. neesii clumps. Additionally, focal observations on bamboo clumps and seed traps were used to verify the predatory impact of $S$. frontalis on $M$. neesii seeds. S. frontalis was present in 6 out 18 point counts in $M$. neesii clumps. The seedeater behaved territorially in bamboo clumps and presented a mean predation rate of 1.10 bamboo seeds/minute. Seed traps had up to $80 \%$ of the seeds predated. The large amount of seeds available during bamboo masting events probably contributes to the maintenance of wandering populations of $S$. frontalis in the Atlantic forest. On the other hand, the predation of seeds by S. frontalis may reduce the reproductive germination and the propagation of the bamboos whose growth may in turn negatively affect the establishment of other forest species.
\end{abstract}

Keywords: bamboos, bird-plant interaction, Emberizidae, foraging behavior, predation rate.

CESTARI, C. \& BERNARDI, C.J. Predação do pixoxó Sporophila frontalis (Aves: Emberizidae) em sementes de Merostachys neesii (Poaceae: Babusoideae) durante um evento de frutificação em massa na floresta Atlântica. Biota Neotrop. 11(3): http://www.biotaneotropica.org.br/v11n3/pt/abstract?shortcommunication+bn00711032011

Resumo: O pixoxó Sporophila frontalis (Verreaux, 1869) é freqüentemente encontrado forrageando em sementes durante eventos de frutificação em massa de bambus na floresta Atlântica. No presente estudo, nós analisamos a atividade de predação de $S$. frontalis em sementes de Merostachys neesii Rupr. durante um evento de frutificação em uma reserva da floresta Atlântica no sudeste do Brasil. Nós conduzimos pontos de contagem em locais com M. neesii e em locais sem bambus ao longo de trilhas para determinar a presença de $S$. frontalis em touceiras de M. neesii. Adicionalmente, observações focais e coletores de sementes foram utilizados em touceiras de $M$. neesii para verificar o impacto de predação em sementes realizado pelo pássaro. Sporophila frontalis esteve presente em 6 de 18 pontos de contagem com touceiras de M. neesii. Esta espécie se comportou territorialmente em touceiras de bambu e apresentou uma taxa de predação média de 1.10 sementes/minuto. Os coletores de sementes possuíram até $80 \%$ das sementes predadas. Provavelmente, a enorme quantidade de sementes disponíveis durante eventos de frutificação em massa de bambus contribuem para a manutenção de populações vagantes de $S$. frontalis na floresta Atlântica. Por outro lado, a predação de sementes por $S$. frontalis pode reduzir a germinação reprodutiva e a propagação de bambus, cujo crescimento interfere negativamente no estabelecimento de outras espécies de plantas arbóreas.

Palavras-chave: bambus, interação ave-planta, Emberizidae, comportamento de forrageio, taxa de predação. 


\section{Introduction}

The bamboos are perennial evergreen plants in the tropics belonging to the true grass family (Poaceae). In the Neotropical region, the highest diversity of bamboos occurs in Brazil (18 genera and 155 species, 129 being endemic) (Filgueiras \& Gonçalves 2004). The Brazilian Atlantic forest is particularly rich in bamboos and some regions have more than 30 species (Judziewicz et al. 1999). The semelparity as a reproductive strategy of these plants has a strong potential to attract seed predators due the huge crop of seeds available during masting events occurring at intervals of 3 to 120 years after which plants die (Numata 1974, Janzen 1976, Campbell 1985).

The competition between bamboo relatives, the climate periodicity and the seed consumer satiation are some potential evolutionary influences that may explain the bamboos mast-seeding events (Janzen 1976, Campbell 1985). In the latter, some birds act as predators and may be ecologically benefited by the enormous availability of seeds. Several bird species are already pointed as associated with bamboos in the Neotropical region (Stotz et al. 1996). Additionally, the increments of bird populations during bamboo fruiting events are widely reported in the literature (Davis 1945, Collar et al. 1992, Olmos 1996, Sick 1997, Vasconcelos et al. 2005, Areta et al. 2009).

An uncontrolled population of bamboo may inhibit the establishment of other arboreal plant species by processes of nutrients competition, obstruction of light and seeds limitation (Smith et al. 1981, Oliveira-Filho et al. 1994, Rother et al. 2009). In this context, seed-predators like birds might contribute to control bamboo populations by limiting successful seedling. In the Atlantic forest, some species of emberizids, e.g., Haplospiza unicolor Cabanis, 1851, Sporophila falcirostris (Temminck, 1820), S. frontalis (Verreaux, 1869), S. schistacea (Lawrence, 1862), and Tiaris fuliginosus (Wied, 1830) are the most observed birds during flowering and fruiting events of several bamboo species, including Chusquea spp., Guadua spp., Merostachys spp., and Parodiolyra spp. (Collar et al. 1992, Olmos 1996, Vasconcelos 2002, Vasconcelos et al. 2005, Sick 1997, Sigrist 2006, Areta \& Bodrati 2008, Areta et al. 2009).

Sporophila frontalis is frequently cited as associated with Merostachys bamboos in Brazil (Vasconcelos 2002, Sick 1997, Sigrist 2006). However, no study has analyzed in details this association. In the present study, we document the feeding association of $S$. frontalis on $M$. neesii in a masting event occurred in the Atlantic forest in southeastern Brazil. We suppose that the bird predatory activity on seeds partially mediates the bamboo population control in the studied area.

\section{Material and Methods}

\section{Study area}

This study was conducted in Ribeirão Grande (24 $15^{\prime}$ '27,6" S and $\left.48^{\circ} 24^{\prime} 07,5^{\prime \prime} \mathrm{W}\right)$ at Fazenda Intervales State Park, located on the Serra de Paranapiacaba, São Paulo state, southeastern Brazil. Great part of the $490 \mathrm{~km}^{2}$ of Fazenda Intervales is formed by a continuous of Atlantic forest vegetation with altitudinal range between 60 and $1.100 \mathrm{~m}$ (Fundação Florestal 2010). Climate in the upper relief (nearly $850 \mathrm{~m}$ ) of the studied region is cool and wet, with average precipitation of $1.600 \mathrm{~mm}$ per year (see Olmos (1996) for more information).

\section{Target species}

Sporophila frontalis is a nomad, rare to uncommon species at forest borders and in regenerating clearings (Ridgely \& Tudor 1994,
Sick 1997). It is considered vulnerable (Birdlife International 2008) and endemic to Atlantic forest (Collar et al. 1992). It is notably arboreal for a seedeater, and it can be briefly more numerous in events of bamboo flowering and masting mainly on mountains of southeastern Brazil (Ridgely \& Tudor 1994, Sick 1997). Population estimates range from 2.500 to 10.000 individuals (Birdlife International 2008). The geographic distribution of this species extends from extreme southern Espirito Santo and south-east Minas Gerais states south through Rio de Janeiro (bulk of individuals) to Rio Grande do Sul in Brazil, eastern Paraguay and Misiones in Argentina (Collar et al. 1992, Birdlife International 2008). According to Birdlife International (2008), the population of $S$. frontalis has been greatly reduced since the late $19^{\text {th }}$ century and its patchily distributed populations experience illegal pet trade and continuing clearance of Atlantic forest. In the studied region, $S$. frontalis is rarely seen, except in bamboo flowering and fruiting periods (pers. comm., staffs of Fazenda Intervales State Park).

The bamboo genus Merostachys includes 53 species, and its geographic distribution ranges from Central America, south to Argentina. Brazil is considered the center of diversity of Merostachys spp. (Soderstrom et al. 1988, Sendulsky 1995). Inter-masting events in Merostachys spp. is sparsely cited in the literature and it may vary from 3 to 34 years (Pereira 1941, Giovannoni et al. 1946, Smith et al. 1981, Sendulsky 1995, 2001, Sick 1997, Guilherme \& Ressel 2001, Jaksic \& Lima 2003, Areta et al. 2009). Sendulsky (2001) cited a flowering cycle of 30-33 years in M. neesii. In the studied region, M. neesii clumps occur in high densities on the border and interior of secondary forests. The dry fruits of $M$. neesii have nearly $1 \mathrm{~cm}$ length and $0.2 \mathrm{~cm}$ width. Each fruit contains one seed.

\section{Methodology}

The presence of $S$. frontalis on Fazenda Intervales State Park was verified using a modified point count method with fixed radius (Bibby et al. 1993). Thirty-three circular points with estimated fixed radius of $20 \mathrm{~m}$ and interspaced in a minimum distance of $10 \mathrm{~m}$ each other were established along $1.500 \mathrm{~m}$ in three trails with the presence of $M$. neesii and without any species of bamboos. The bird censuses were carried out between 6:30 to 11:00 AM. in 09 March 2010. All the individuals of $S$. frontalis seen and heard were counted during 5 minutes per point. Considering the geographical conditions of the study area and the bird movements, we judged this short census period adequate to avoid records of the same individuals of $S$. frontalis in neighboring circular points along the trails. On the same morning, seven added focal points of 30 minutes each were used to observe $S$. frontalis feeding on $M$. neesii clumps in one of the trails.

Three seed traps of $1.75 \mathrm{~m}^{2}$ were also installed below the M. neesii infrutescences during all day (6:30 AM - 4:30 PM) to quantify the number of seeds predated. We considered a predation when the seed was removed (by the bird) from the dry fruit's sheath that completely covers it. As a result, we obtained the proportion of seeds consumed (predated) by $S$. frontalis. We presumed that the seeds were predated by $S$. frontalis due the inexistence of another bird species foraging in $M$. neesii clumps during the diurnal focal observations on the points and the mainly nocturnal feeding activity of rodents (Bergallo 1994). During all the observation time, only one individual of Uniform Finch (Haplospiza unicolor) was recorded moving through one bamboo clump with no active feeding behavior. Olmos (1996), reported the association of H. unicolor with Chusquea meyeriana in the same study area. There are also evidences pointing that the size and morphology of the bill of H. unicolor are better suited to forage in the smaller seeds of Chusquea spp. than on Merostachys spp. (Areta et al. 2009). 


\section{Results}

Considering the 33 point counts, 18 had M. neesii clumps and we recorded eight individuals of $S$. frontalis in six points with the bamboo. Normally, only one individual per point count was recorded, except in one of the points where two individuals were recorded during an agonistic encounter. These observations indicate territoriality of the birds. Additionally, we recorded the foraging behavior of $S$. frontalis in $M$. neesii clumps in four of the seven focal points. Mean feeding rate was $1.10 \pm 0.55$ seeds preyed upon/minute (range: 0.53 - 2.06) (Table 1).

During the seed feeding, S. frontalis generally perched firmly in the main bamboo culm or in a more slender twig near the dry infrutescence extending the neck upwards, outwards or downwards to reach the fruits and pick the seeds (Figure 1). Individuals squeezed the dry fruit and removed the seed with bill movements before dropping the fruit's sheath. Birds had easy access to several dry fruits and seeds when perching in one twig.

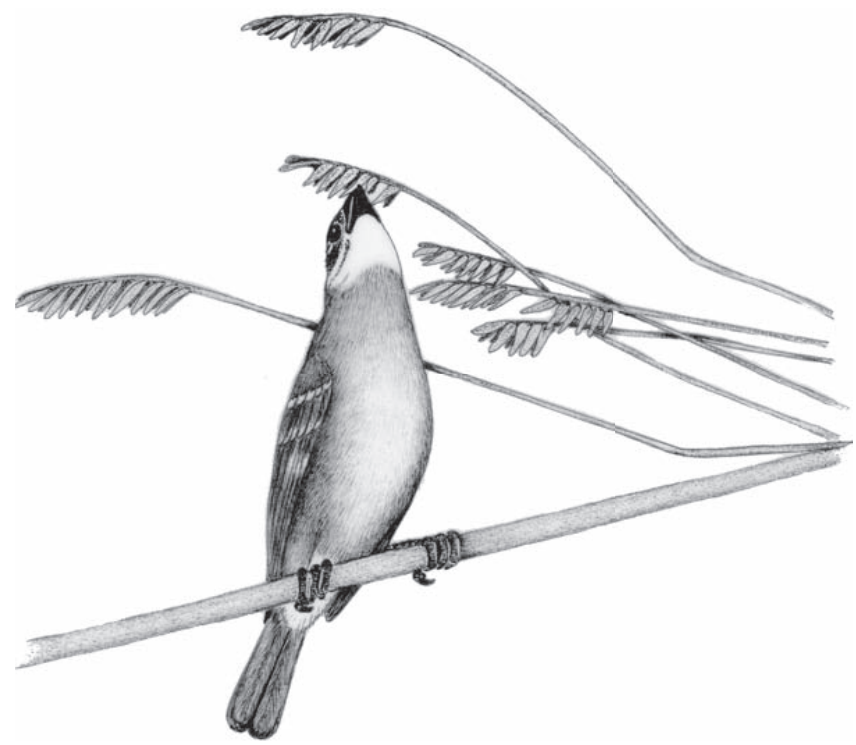

Figure 1. S. frontalis reaching a dry fruit of M. neesii in Fazenda Intervales State Park. (Illustration by Jaime Roberto Somera).

Figura 1. S. frontalis alcançando um fruto seco de M. neesii no Parque Estadual fazenda intervales (Ilustração de Jaime Roberto Somera).
All the seed traps had more than a half of the seeds predated, with values reaching up to $80 \%$ in two of them, indicating a high predation activity of $S$. frontalis (Figure 2).

\section{Discussion}

Synchronized masting events on bamboos are pointed out as an extraordinary example of seed predator satiation (Janzen 1976). Granivorous birds specialized on bamboos depend on the ephemeral seed resource available at large intervals of time and they have to wander actively to find these resources (Neudorf \& Blanchfield 1994, Areta et al. 2009). Apparently, this is the case of S. frontalis in Atlantic forest (Collar et al. 1992, Sick 1997).

The masting event of $M$. neesii produces millions of seeds simultaneously, likely satiating all kinds of potential predator species (e.g. birds, rodents) (Olmos 1996, Sick 1997, Areta et al. 2009). For instance, our results estimated the mean of $19 \pm 8$ seeds per hour in the $1.75 \mathrm{~m}^{2}$ seed traps as a coarse example of large seed production. Taking this into account, one bird might predate this amount of seeds in approximately 18 minutes. Although we did not have the precise number of birds and seed production on bamboo clumps in the entire study area, the amount of seeds predated by $S$. frontalis must be considered to the control of bamboo populations. The importance of $S$. frontalis as control species of $M$. neesii increases regarding the simultaneous spatial depletion of the seeds as resultant effect of bird territoriality. Once seeds were depleted in bamboo clumps, populations of $S$. frontalis probably will move to others suitable feeding areas.

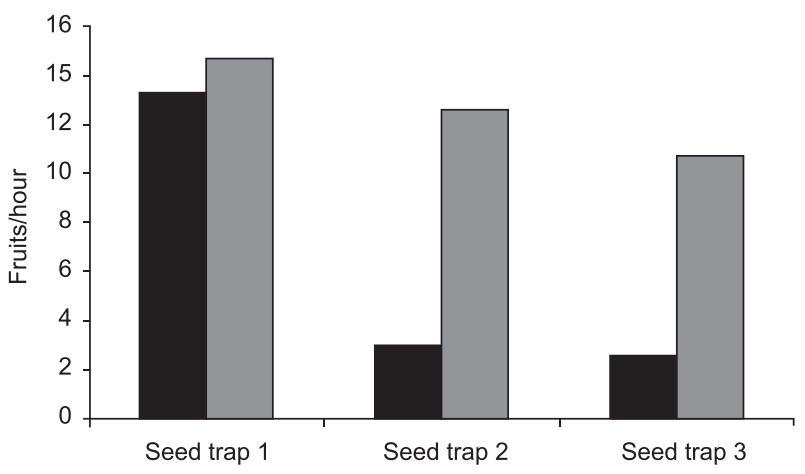

Figure 2. Number of fruits per hour collected in $1.75 \mathrm{~m}^{2}$ seed traps disposed below of $M$ neesii thickets in Fazenda Intervales State Park. The black bars are intact (non-predated) fruits and the white bars are predated fruits.

Table 1. Focal points, time of observation per point, contacts of individuals per point, and feeding activity of $S$. frontalis on seeds of $M$. neesii at Fazenda Intervales State Park.

\begin{tabular}{ccccc}
\hline Focal point & Time of observation & $\begin{array}{c}\text { Contact of } \\
\text { individual }\end{array}$ & Predated seeds & $\begin{array}{c}\text { Feeding rate } \\
\text { (seeds/minute) }\end{array}$ \\
\hline$\# 1$ & $6: 30$ to $7: 00$ & - & - & - \\
$\# 2$ & $7: 05$ to $7: 35$ & - & - & - \\
$\# 3$ & $7: 40$ to $8: 10$ & $\# 1$ & 42 & 1.06 \\
& & $\# 2$ & 62 & 0.53 \\
$\# 4$ & & $\# 3$ & 48 & 2.06 \\
$\# 5$ & $8: 15$ to $8: 45$ & $\# 4$ & - & 0.80 \\
$\# 6$ & $8: 50$ to $9: 20$ & $\# 5$ & - & 23 \\
\hline 7
\end{tabular}

*The term contact of individual was used due the uncertainness to verify if individuals feeding on seeds were the same one. There were occasions that one bird left the bamboo clump and then a bird returned and fed upon the seeds. 
S. frontalis inhabits mainly the interior and borders of forested areas (Ridgely \& Tudor 1994, Sick 1997, Collar et al. 1992). These are also the areas in which the plants suffer the negative effects caused by the bamboos, mainly due to nutrients competition, obstruction of light and limitation of seed dispersal (Smith et al. 1981, Oliveira-Filho et al. 1994, Rother et al. 2009). Thus, we argue that seed predation by $S$. frontalis may render a self-species benefit effect, helping in the maintenance of their native arboreal habitats, and in turn, keeping its own populations wealthy. This endemic and vulnerable bird from the Atlantic forest has as major threats the continuing forests clearance and illegal pet trade (Collar et al. 1992, Birdlife International 2008). In some occasions, the forests destruction is faster than the bamboo fruit masting events, and local disappearance of $S$. frontalis have been reported for some Brazilian regions (Vasconcelos 2002).

In addition to Merostachys spp., S. frontalis was also present at masting events of Guadua and Chusquea bamboos in the Atlantic forest, and anthropogenic scenarios of rice cultivated areas (Sick 1997, Fitorra et al. 2008, Areta et al. 2009). Probably, this granivorous species feeds on more species of bamboos, and its predation activity contributes to reduce the predominance of Poaceae over other forest plants of this biome.

\section{Acknowledgements}

We thank the company of all the students, colleagues and advisors (B. Garcia, J. M. Gomez, M. A. Pizo, M. Galetti, P. Jordano and W. Silva) who gently helped us with their knowledge and field assistance during the Latin-American Frugivory Course. We are also grateful to J. R. Somera that kindly illustrated the bird picture and two anonymous reviewers for suggestions and improvements of this manuscript. C. Cestari has a research grant from the Brazilian Research Council (CNPq).

\section{References}

ARETA, J.L. \& BODRATI, A. 2008. Comportamiento, identificación y relación con la floración de cañas del Espiguero Negro (Tiaris fuliginosa) en Misiones, Argentina. Hornero. 23(2):77-86.

ARETA, J.L., BODRATI, A. \& COCLKE, K. 2009. Specialization on Guadua bamboo seeds by three bird species in the Atlantic forest of Argentina. Biotropica. 41(1):66-73. http://dx.doi.org/10.1111/j.17447429.2008.00458.x

BERGALLO, H.G. 1994. Ecology of a small mammal community in an Atlantic forest area in Southeastern Brazil. Stud. Neotrop. Fauna Envir. 29(4):197-217. http://dx.doi.org/10.1080/01650529409360932

BIBBY, C.J., BURGES, N.D. \& HILL, D.A. 1993. Bird Census Techniques. The Academic Press, Cambridge.

BIRDLIFE INTERNATIONAL. 2008. Sporophila frontalis. In IUCN Red List of Threatened Species (International Union for Conservation of Nature - IUCN). Version 2010.1. Disponível em http://www.iucnredlist. org (último acesso em 25/03/2010).

CAMPBELL, J.N. 1985. Bamboo flowering patterns: a global view with special reference to East Asia. J. Am. Bam. Soc. 1(6):17-35.

COLLAR, N.J., GONZAGA, L.P., KRABBE, N., MADROÑO NETO, A., NARANJO, L.G., PARKER III, T.A \& WEGE, D.C. 1992. Threatened birds of the Americas: the ICBP/IUCN Red Data Book. Smithsonian Institution Press, Cambridge.

DAVIS, D.E. 1945. The annual cycle of plants, mosquitoes, birds and mammals in two Brazilian forests. Ecol. Monogr. 15(3):243-295. http:// dx.doi.org/10.2307/1943247

FILGUEIRAS, T.S. \& GONÇALVES, A.P.S. 2004. A checklist of the basal grasses and bamboos in Brazil. J. Am. Bam. Soc. 1(18):7-18.
FITORRA, L.S., MILANELO, L., PETRI, B.S.S., MOREIRA, M.B \& ALVES, M. 2008. Registro de ocorrência de Sporophila frontalis (Emberizidae) no município de Miracatu - SP associado à floração de Chusquea sellowi (Poacea). In Livro de Resumos do XXVII Congresso Brasileiro de Ornitologia. SBO, Aracruz, p.165.

FUNDAÇÃO FLORESTAL. 2010. Unidades de conservação do Estado de São Paulo. Disponível em http://www.fflorestal.sp.gov.br (último acesso em 25/03/2010).

GIOVANNONI, M., VELLOZO, L.G.C. \& KUBIAK, G.V.L. 1946. Sobre as "ratadas" do primeiro planalto paranaense. Arq. Biol. Tecnol. 1(1):185-195.

GUILHERME, F.A.G. \& RESSEL, K. 2001. Biologia floral e sistema de reprodução de Merostachys riedeliana (Poaceae: Bambusoideae). Rev. Bras. Bot. 2(24): 205-211. http://dx.doi.org/10.1590/S010084042001000200011

JAKSIC, F.M. \& LIMA, M. 2003. Myths and facts about ratadas: bamboo blooms, rainfall peaks and rodent outbreaks in South America. Aust. Ecol. 28(3):237-251. http://dx.doi.org/10.1046/j.14429993.2003.01271.x

JANZEN, D.H. 1976. Why bamboos wait so long to flower? Ann. Rev. Ecolog. Syst. 7(1):347-391. http://dx.doi.org/10.1146/annurev. es.07.110176.002023

JUDZIEWICZ, E.J, CLARK, L.G, LONDOÑO, X. \& STERN, M.J. 1999. American bamboos. Smithsonian Institution Press, Washington.

NEUDORF, D.L. \& BLANCHFIELD, P.J. 1994. The Slate-colored Seedeater (Sporophila schitacea): a bamboo specialist? Ornitol. Neotrop. 5(2):129-132.

NUMATA, M. 1974. Ecology aspects of bamboo flowering. Ecological studies of bamboo forests in Japan. Bot. Manag. Tok. 87(4):271-284. http://dx.doi.org/10.1007/BF02489558

OLIVEIRA-FILHO, A.T., VILELA, E.A., GALVILANES, M.L. \& CARVALHO, D.A. 1994. Effect of flooding regime and understorey bamboos on the physiognomy and tree species composition of a tropical semideciduous forest in southeastern Brazil. Vegetatio. 113(2):99-124.

OLMOS, F. 1996. Satiation or deception? Mast-seeding Chusquea bamboos, birds and rats in the Atlantic Forest. Rev. Bras. Biol. 56(2):391-401.

PEREIRA, C. 1941. Sobre as "ratadas" no sul do Brasil e o ciclo vegetativo das taquaras. Arq. Inst. Biol. São Paulo. 12(14):175-195.

RIDGELY, R. \& TUDOR, G. 1994. The Birds of South America. Oscines Passerines. University of Texas Press, Austin.

ROTHER, D.C., RODRIGUES, R. \& PIZO, M.A. 2009. Effects of bamboo stands on seed rain and seed limitation in a rainforest. For. Ecol. Manage 257(3):885-892. http://dx.doi.org/10.1016/j.foreco.2008.10.022

SENDULSKY, T. 1995. Merostachys multiramea (Poaceae: Bambusoideae: Bambuseae) and similar species from Brazil. Novon 5(1):76-96. http:// dx.doi.org/10.2307/3391839

SENDULSKY, T. 2001. Merostachys Spreng. (Poaceae, Bambusoideae, Bambuseae): a new species from Brazil and critical notes on "group Speciosa". Kew Bull. 56(3):627-638. http://dx.doi.org/10.2307/4117687

SICK, H. 1997. Ornitologia Brasileira. Nova Fronteira, Rio de Janeiro.

SIGRIST, T. 2006. Aves do Brasil: uma visão artística. Ministério da Cultura, São Paulo.

SMITH, L.B., WASSHAUSEN, D.C \& KLEIN, R.M. 1981. Gramíneas. In Flora Ilustrada Catarinense (R. Reitz, ed.). Herbário Barbosa Rodrigues, Itajaí, p.911-1099

SODERSTROM, T.R., JUDZIEWICZ, E.J. \& CLARK, L.G. 1988. Distribution patterns of neotropical bamboos. In Proceedings of a workshop on neotropical distribution patterns (P. E. VANZOLINI, W. R. HEYER, eds.). Academia Brasileira de Ciências, Rio de Janeiro, p.121-157. 
Predation of the Buffy-fronted Seedeater Sporophila frontalis (Aves: Emberizidae) on Merostachys neesii (Poaceae: Babusoideae) seeds

STOTZ, D.F, FITZPATRICK, J.W., PARKER, T.A. \& MOSKOVITS,

D.K. 1996. Neotropical birds: ecology and conservation. University of Chicago Press, Chicago.

VASCONCELOS, M.F. 2002. O pixoxó (Sporophila frontalis) nos municípios de Serro e Santa Bárbara, Minas Gerais: possíveis casos de extinções locais. Atual. Ornitol. 106:2.
VASCONCELOS, M.F., VASCONCELOS, A.P, VIANA, P.L., PALÚ, L. \& SILVA, J.F 2005. Observações sobre aves granívoras (Columbidae e Emberizidae) associadas à frutificação de taquaras (Poaceae, Bambusoideae) na porção meridional da Cadeia do Espinhaço, Minas Gerais, Brasil. Lundiana 6(1):75-77. 